\title{
Salt tolerance classification of winter cereal varieties according to grain yield performance and water use efficiency
}

\author{
N. Katerji ${ }^{1}$, M. Mastrorilli ${ }^{2}$, M. M. Nachit ${ }^{3}$, J. W. van Hoorn ${ }^{4}$, \\ A. Hamdy ${ }^{5}$, T. Oweis ${ }^{3}$, O. Abdalla ${ }^{3} \&$ S. Grando ${ }^{3}$ \\ ${ }^{1}$ INRA, Grignon, France \\ ${ }^{2}$ CRA-SCA, Bari, Italy \\ ${ }^{3}$ ICARDA, Aleppo, Syria \\ ${ }^{4}$ Sub-department Water Resources, Wageningen University, \\ The Netherlands \\ ${ }^{5}$ CIHEAM-IAM, Valenzano, Italy
}

\begin{abstract}
Irrigation management with nonconventional waters (saline water, reused drainage-water, waste-water) require the identification of varieties which are adapted to saline conditions. The study aims to identify the varieties which combine high yield with the efficiency in using irrigation waters of different qualities. Durum wheat, barley and winter wheat showed an ascendant curvilinear relationship between grain yield and water use efficiency. The durum wheat varieties showed large differences in grain yield that increased at increasing salinity. Barley also showed large differences between the varieties, even more pronounced than durum wheat but not increasing with salinity. Among the bread wheat varieties only one variety was less suitable under saline conditions. The durum wheat varieties (Cham.1 and Belikh.2) and the barley varieties (California Mariout) and Melusine/A) present a combination of high yield and high water use efficiency in a saline environment, whereas the bread wheat variety (Johara.14) is less suitable under saline conditions than the other varieties. The varietal selection combining high yield and high water use efficiency constitutes an important point with respect to managing irrigation with saline waters.
\end{abstract}

Keywords: barley, durum wheat, bread wheat, water salinity, drought, water use efficiency. 


\section{Introduction}

When assessing the suitability of saline irrigation water, the choice of varieties adapted to saline conditions plays an important role (Rhoades et al. [1], Minhas [2]). Agronomists prefer varieties with the highest yield in a saline environment (Reitz [3]). Irrigation specialists often do not take yield as a leading indicator (Pereira et al. [4]), but they prefer the water use efficiency to identify the best irrigation scheduling strategies (Shideed et al. [5]) and to analyse the water saving performance of irrigation systems (Ayars et al. [6]).

The water use efficiency of cereals is defined as the ratio between grain yield and total evapotranspiration (Sinclair et al. [7]). The choice of the water use efficiency is well justified, because a high valorization of saline water means at the same time water economy and less salt input (Burt et al. [8]). Sinclair and Muchow [9] underline the complementariness of both indicators and suggest to select varieties presenting high yield together with high water use efficiency.

Research on links between yield and water use efficiency is a new approach in the selection of cereal varieties tolerant to drought or salinity. Actually, no information is available on the relationship between yield and water use efficiency of cereal varieties under saline conditions. The comparison of cereal varieties in a saline environment of Kingsbury and Epstein [10] and the most recent one of El-Hendawy [11] do not take into account evapotranspiration and water use efficiency. Data, however, are available on the relationship between yield and water use efficiency under non-saline conditions for trials conducted on winter cereals growing irrigated or non-irrigated conditions in the Mediterranean region. The results for winter cereals vary between the species. Bread wheat shows a curvilinear relationship without a maximum (Zhang and Oweis [12]). Whereas durum wheat shows a maximum in its curvilinear relationship, indicating a decrease of the water use efficiency at very high yields (Oweis and Zhang [13]). The approach based on multi-location trials for drought and salinity studies is not recommended, as other interacting factors are involved in the experiment. According to Maas and Grattan [14] it is not always clear if the varietal differences reflect differences in salt tolerance or differences in adaptation to the particular climatic or nutritional conditions under which the crops were tested.

This study comprises three experiments with varieties of durum and bread wheat and barley at three salinity levels. The trials were conducted in greenhouse, which permits to measure simultaneously evapotranspiration on a large number of cultivars and repetitions. The aim of this study was as follows: 1) to relate yield and water use efficiency in saline water for the three Mediterranean winter cereals (durum wheat, bread wheat, and barley); and 2) within each species, to study the relationship between salt tolerance rankings and water use efficiency.

\section{Material and methods}

The experiments were done in a greenhouse (inside temperature $20^{\circ} \mathrm{C}$ ) at Bari, southern Italy. The set-up consisted of micro-lysimeters with a diameter of $0.4 \mathrm{~m}$, 
Table 1: $\quad$ Composition of irrigation water $\left(\mathrm{mmol} \mathrm{l}^{-1}\right)$.

\begin{tabular}{crrrrrrr}
\hline $\mathrm{EC}(\mathrm{dS} / \mathrm{m})$ & $\mathrm{Ca}^{2+}$ & $\mathrm{Mg}^{2+}$ & $\mathrm{Na}^{+}$ & $\mathrm{K}^{+}$ & $\mathrm{Cl}^{-}$ & $\mathrm{HCO}_{3}{ }^{-}$ & $\mathrm{SO}_{4}{ }^{2-}$ \\
\hline 0.9 & 4.0 & 3.4 & 1.6 & 0.5 & 3.2 & 6.0 & 0.3 \\
\hline 4 & 6.5 & 14.0 & 22.0 & 1.3 & 36.0 & 5.8 & 2.0 \\
\hline 5 & 6.6 & 8.4 & 40.0 & 0.8 & 45.0 & 8.0 & 7.0 \\
\hline 8 & 7.8 & 20.0 & 48.0 & 2.7 & 70.0 & 6.0 & 2.5 \\
\hline 10 & 8.2 & 19.4 & 78.6 & 1.4 & 80.0 & 8.0 & 12.0 \\
\hline
\end{tabular}

Table 2: $\quad$ The cultivars.

\begin{tabular}{|c|c|c|}
\hline \multicolumn{3}{|r|}{ DURUM WHEAT } \\
\hline V1 & Omrabi.5 & $\begin{array}{l}\text { ICARDA breeding line, high yielding, widely adapted, drought } \\
\text { tolerant; released in Jordan, Iran, Turkey, and Iraq }\end{array}$ \\
\hline V2 & Hagla & ICARDA breeding line, salt tolerant \\
\hline V3 & Haurani & $\begin{array}{l}\text { Syrian Landrace was grown on large scale in Syria, Lebanon, } \\
\text { Jordan, and Turkey }\end{array}$ \\
\hline V4 & Gidara 2 & $\begin{array}{l}\text { ICARDA breeding line, high yielding in continental areas, cold } \\
\text { tolerant; released in Turkey }\end{array}$ \\
\hline V5 & Cham.1 & $\begin{array}{l}\text { ICARDA breeding line, high yielding, good performance under } \\
\text { higher rainfall and supplementary irrigation; released in several } \\
\text { Mediterranean countries. }\end{array}$ \\
\hline V6 & $\begin{array}{l}\text { Jennah } \\
\text { Khetifa }\end{array}$ & Landrace \\
\hline V7 & Belikh.2 & $\begin{array}{l}\text { ICARDA breeding line, high yielding, some salt tolerance; } \\
\text { released in Lebanon and Syria }\end{array}$ \\
\hline \multicolumn{3}{|r|}{ BARLEY } \\
\hline V1 & Arar & ICARDA breeding line, , drought resistant, 2 rowed \\
\hline $\mathrm{V} 2$ & Arta & ICARDA breeding line, drought resistant, 2 rowed \\
\hline V3 & $\begin{array}{l}\text { California } \\
\text { Mariout }\end{array}$ & 6 rowed, resistant to drought, salinity and diseases \\
\hline V4 & Zanbaka & 2 rowed \\
\hline V5 & WI2737 & ICARDA breeding line, selected for high yield potential, 2 rowed \\
\hline V6 & Melusine/A & $\begin{array}{l}\text { ICARDA/CIMMYT breeding line, selected for high yield } \\
\text { potential, } 2 \text { rowed }\end{array}$ \\
\hline \multicolumn{3}{|r|}{ BREAD WHEAT } \\
\hline V1 & Sakha.8 & Egyptian breeding line, irrigated crop, salt tolerant \\
\hline $\mathrm{V} 2$ & Cham. 8 & ICARDA breeding line, irrigated crop, salt sensitive \\
\hline $\mathrm{V} 3$ & Cham.6 & ICARDA breeding line, dry land crop \\
\hline V4 & Haamam.4 & ICARDA breeding line, dry land crop \\
\hline V5 & Qafzah.8 & ICARDA breeding line, dry land crop \\
\hline V6 & Qimma.5 & ICARDA breeding line, dry land crop \\
\hline V7 & Johara.14 & ICARDA breeding line, dry land crop \\
\hline
\end{tabular}


a height of $0.6 \mathrm{~m}$. The lysimeter was filled with clay soil. Table 1 presents the chemical composition of the irrigation waters. The used crop cultivars (table 2) were developed for their high productivity and drought tolerance (Nachit and Elouafi [15] for durum wheat, Ceccarelli [16] for barley, and Ortiz-Ferrara and Abdalla [17] for beard wheat). No data are available about the salt tolerance, except for durum wheat where preliminary studies were made on limited cultivars (Almansouri et al. [18]).

Evaporation (class A pan) was used to schedule irrigations. Evapotranspiration (ET of the irrigation interval) was calculated as the difference between the amounts of irrigation and drainage water. Table 2 presents the studied varieties.

Fertilization doses were 150,100 and $120 \mathrm{Kg} / \mathrm{ha}$ of $\mathrm{P}_{2} \mathrm{O}_{5}, \mathrm{~K}_{2} \mathrm{O}$ and $\mathrm{N}$.

The durum wheat experiment comprised 63 lysimeters ( 7 varieties x 3 water qualities x 3 replicates), the barley 72 (6 varieties x 3 waters x 4 replicates), and the bread wheat 84 ( 7 varieties $\times 3$ waters $x 4$ replicates).

The variables understudy in the experiments were analyzed with two-way ANOVA followed by multiple pair wise comparisons (Student-Neuman-Keuls test).

\section{Results and discussion}

Figure 1 presents the relationship between yield and WUE. The curves of barley and bread wheat are similar to those observed for crops (Zhang and Oweis [12]; Zhang et al. [19]; Oweis et al. [20]) cultivated in fields with or without irrigation. A difference, however, exists between our observations and those of Zhang and Oweis of durum wheat. The latter showed a maximum of water use efficiency at a yield of $0.6 \mathrm{Kg} / \mathrm{m}^{2}$, after which the water use efficiency declined.

The decline of the WUE in the study of Zhang and Oweis could be attributed to the evapotranspiration not being measured, but calculated. In case of heavy rainfall and irrigation runoff and drainage cannot be neglected (Katerji et al. [21]) and a simplified water balance leads to overestimating the evapotranspiration and underestimating the water use efficiency (Rana and Katerji [22]).

The WUE data found in the present study conducted under greenhouse conditions are similar to those generated under field conditions. In the case of durum wheat, the average value for WUE on 7 cultivars is $1.37 \mathrm{Kg} / \mathrm{m}^{3}(1.19$ $\mathrm{Kg} / \mathrm{m}^{3} \pm 0.2$ according Zhang and Oweis [12]) and $1.9 \mathrm{Kg} / \mathrm{m}^{3}$ for bread wheat (from 1 to $2.5 \mathrm{Kg} / \mathrm{m}^{3}$, according Oweis [23]). The high WUE for bread wheat in comparison with durum wheat is in agreement with breeders observations (Nachit et al. [24]). As irrigation is not practiced in barley, therefore no WUE studies were undertaken in this present study.

The ranking of the durum wheat varieties in Table 3 shows almost the same order for yield and for water use efficiency, as it was expected from the strong relationship between yield and water use efficiency in Figure 1.

Salinity has little effect on the order of ranking. However, some slight changes have occurred. For example, in the case of fresh water the varieties V1, V2 and V3 show a significantly lower yield than variety V6, whereas only the 

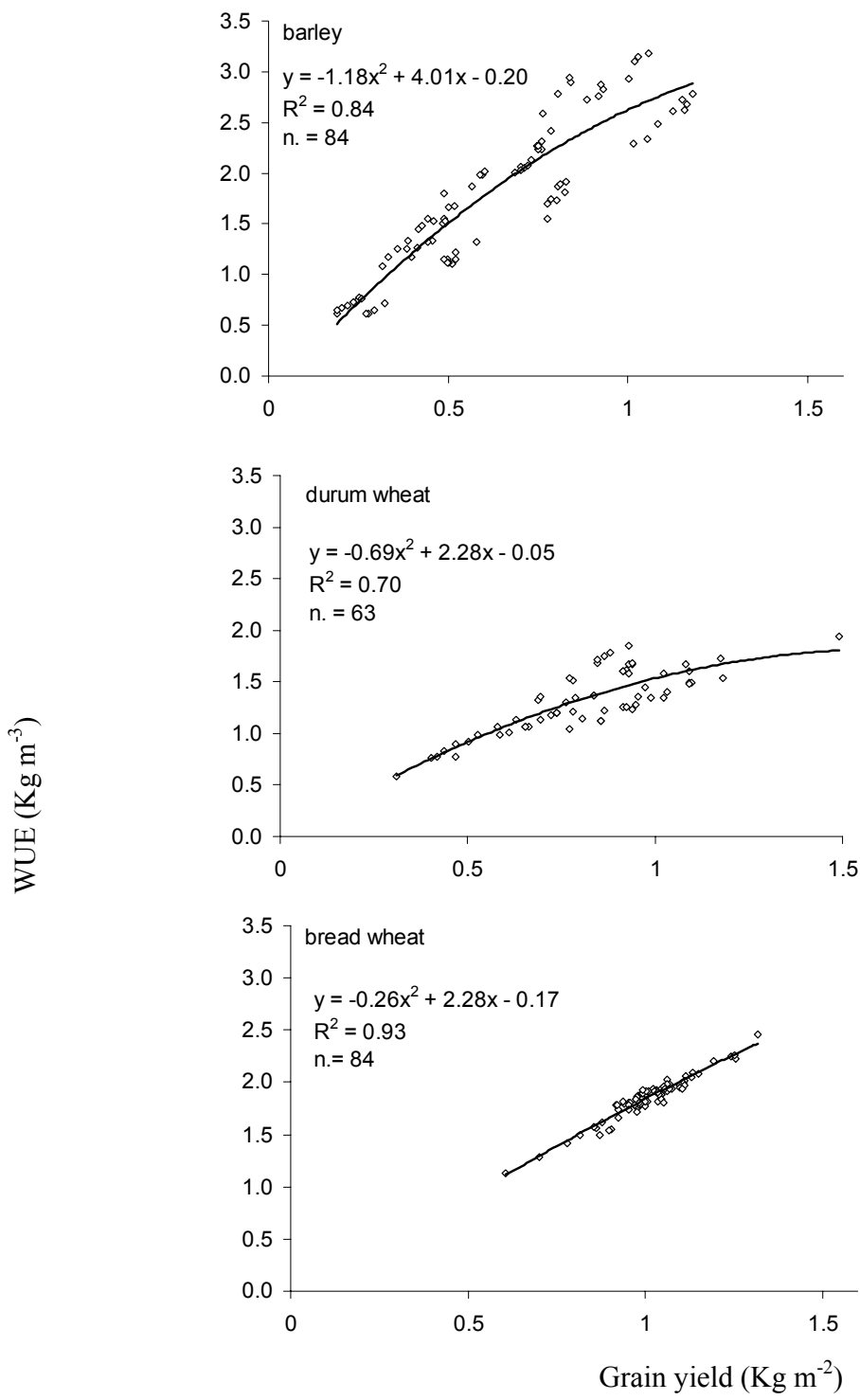

Figure 1: $\quad$ Water use efficiency (WUE) and crop yield for barley, bread and durum wheat.

water use efficiency of variety V3, is significantly lower than that of variety V6. In the case of the most saline treatment, the varieties V1, V2 and V3 present the lowest water use efficiency, whereas only the varieties V1 and V3 show the lowest yield. 
Salinity, however, affects the differences between the durum wheat varieties, which increased at increasing salinity. At the lowest salinity level (ECW 0.9 $\mathrm{dS} / \mathrm{m}$ ), the average yield of the varieties $\mathrm{V} 1$ and $\mathrm{V} 3$ attains $77 \%$ of the average yield of the varieties V5, V6 and V7 against 50\% at the highest salinity level (ECw $8 \mathrm{dS} / \mathrm{m}$ ).

Table 3: Durum wheat irrigated using 3 water qualities (ECw): classifications of 7 varieties according to yield and WUE.

\begin{tabular}{|c|c|c|c|c|}
\hline $\begin{array}{l}\mathrm{ECW} \\
\left(\mathrm{dSm}^{-1}\right)\end{array}$ & Variety & $\begin{array}{l}\text { Yield } \\
\left(\mathrm{Kg} \mathrm{m}^{-2}\right)\end{array}$ & Variety & $\begin{array}{l}\text { WUE } \\
\left(\mathrm{Kg} \mathrm{m}^{-3}\right)\end{array}$ \\
\hline \multirow{7}{*}{0.9} & V6 & $1.23 \mathrm{a}$ & V6 & $1.61 \mathrm{a}$ \\
\hline & V7 & $1.08 \mathrm{ab}$ & V7 & $1.59 \mathrm{a}$ \\
\hline & V5 & $1.07 \mathrm{ab}$ & V5 & $1.45 \mathrm{ab}$ \\
\hline & V4 & $0.99 \mathrm{ab}$ & V4 & $1.34 \mathrm{ab}$ \\
\hline & V2 & $0.89 \mathrm{~b}$ & V1 & $1.24 \mathrm{ab}$ \\
\hline & V3 & $0.88 \mathrm{~b}$ & V2 & $1.21 \mathrm{ab}$ \\
\hline & V1 & $0.87 \mathrm{~b}$ & V3 & $1.16 \mathrm{~b}$ \\
\hline \multirow{7}{*}{4.0} & V6 & $0.96 \mathrm{a}$ & V5 & $1.68 \mathrm{a}$ \\
\hline & V5 & $0.94 \mathrm{ab}$ & V7 & $1.61 \mathrm{a}$ \\
\hline & V7 & $0.92 \mathrm{ab}$ & V6 & $1.49 \mathrm{a}$ \\
\hline & V4 & $0.77 \mathrm{bc}$ & V4 & $1.26 \mathrm{~b}$ \\
\hline & V2 & $0.74 \mathrm{c}$ & V2 & $1.21 \mathrm{~b}$ \\
\hline & V3 & $0.67 \mathrm{~cd}$ & V3 & $1.09 \mathrm{bc}$ \\
\hline & V1 & $0.56 \mathrm{~d}$ & V1 & $0.93 \mathrm{c}$ \\
\hline \multirow{7}{*}{8.0} & V7 & $0.86 \mathrm{a}$ & V7 & $1.76 \mathrm{a}$ \\
\hline & V5 & $0.85 \mathrm{a}$ & V5 & $1.69 \mathrm{a}$ \\
\hline & V6 & $0.83 \mathrm{a}$ & V6 & $1.41 \mathrm{~b}$ \\
\hline & V4 & $0.72 \mathrm{a}$ & V4 & $1.40 \mathrm{~b}$ \\
\hline & V2 & $0.57 \mathrm{~b}$ & V2 & $1.04 \mathrm{c}$ \\
\hline & V1 & $0.44 \mathrm{c}$ & V1 & $0.83 \mathrm{c}$ \\
\hline & V3 & $0.42 \mathrm{c}$ & V3 & $0.80 \mathrm{c}$ \\
\hline
\end{tabular}

F-values (ANOVA: 7 varieties, 3 salinity levels, 3 repetitions).

Dependent variable yield: variety, $31.3>3.29=(6,40 ; 0.01)$, highly significant; $\mathrm{ECw}$, $87.0>5.18=(2,40 ; 0.01)$, highly significant; interaction, $1.47<1.71=(12,40 ; 0.10)$, not significant.

Dependent variable WUE: variety, $40.9>3.29=(6,40 ; 0.01)$, highly significant; $\mathrm{ECw}, 2.9>2.44=(2,40 ; 0.10)$, low significant; interaction, $3.3>2.66=(12,40$; $0.01)$, highly significant.

Values followed by the same letter are not significantly different at $\mathrm{P}<0.05$ according to the Student-Neuman-Keuls test.

Barley in Table 4 shows the same picture as durum wheat: similar order of ranking according to yield and water use efficiency and little effect of salinity on the varietal ranking. Differences between the varieties do not increase at increasing salinity. At the lowest salinity level the average yield of the varieties V1 and V4 attains $48 \%$ of the average yield of the varieties V3 and V6 against 
Table 4: $\quad$ Barley irrigated using 3 water qualities (ECw): classification of 6 varieties according to yield and WUE.

\begin{tabular}{|c|c|c|c|c|}
\hline $\begin{array}{l}\mathrm{ECw} \\
\left(\mathrm{dSm}^{-1}\right)\end{array}$ & Variety & $\begin{array}{l}\text { Yield } \\
\left(\mathrm{Kg} \mathrm{m}^{-2}\right)\end{array}$ & Variety & $\begin{array}{l}\text { WUE } \\
\left(\mathrm{Kg} \mathrm{m}^{-3}\right)\end{array}$ \\
\hline \multirow{6}{*}{0.9} & V3 & $1.15 \mathrm{a}$ & V3 & $2.68 \mathrm{a}$ \\
\hline & V6 & $1.07 \mathrm{~b}$ & V6 & $2.44 \mathrm{~b}$ \\
\hline & V5 & $0.81 \mathrm{c}$ & V5 & $1.90 \mathrm{c}$ \\
\hline & $\mathrm{V} 2$ & $0.81 \mathrm{c}$ & $\mathrm{V} 2$ & $1.71 \mathrm{~d}$ \\
\hline & V1 & $0.54 \mathrm{~d}$ & V4 & $1.23 \mathrm{e}$ \\
\hline & V4 & $0.52 \mathrm{~d}$ & V1 & $1.20 \mathrm{e}$ \\
\hline \multirow{6}{*}{5.0} & V3 & $1.03 \mathrm{a}$ & V3 & $3.09 \mathrm{a}$ \\
\hline & V6 & $0.91 \mathrm{~b}$ & V6 & $2.80 \mathrm{~b}$ \\
\hline & V5 & $0.76 \mathrm{c}$ & V5 & $2.32 \mathrm{c}$ \\
\hline & V2 & $0.73 \mathrm{c}$ & V2 & $2.15 \mathrm{~d}$ \\
\hline & V2 & $0.46 \mathrm{~d}$ & V4 & $1.41 \mathrm{e}$ \\
\hline & V1 & $0.46 \mathrm{~d}$ & V1 & $1.39 \mathrm{e}$ \\
\hline \multirow{6}{*}{10.0} & V6 & $0.81 \mathrm{a}$ & V6 & $2.80 \mathrm{a}$ \\
\hline & V3 & $0.71 \mathrm{~b}$ & V3 & $2.06 \mathrm{~b}$ \\
\hline & $\mathrm{V} 2$ & $0.59 \mathrm{c}$ & V2 & $1.96 \mathrm{~b}$ \\
\hline & V5 & $0.49 \mathrm{~d}$ & V5 & $1.66 \mathrm{c}$ \\
\hline & V4 & $0.42 \mathrm{e}$ & V4 & $1.45 \mathrm{~d}$ \\
\hline & V1 & $0.35 \mathrm{f}$ & V1 & $1.19 \mathrm{e}$ \\
\hline
\end{tabular}

F-values (ANOVA: 6 varieties, 3 salinity levels, 4 repetitions).

Dependent variable yield: variety, $761.5>3.51=(5,51 ; 0.01)$, highly significant; ECw, $492.2>5.18=(2,51 ; 0.01)$, highly significant; interaction, $25.6>2.80=(10,51$; 0.01 ), highly significant.

Dependent variable WUE: variety, $442.2>3.51=(5,51 ; 0.01)$, highly significant; ECw, $95.8>5.18=(2,51 ; 0.01)$, highly significant; interaction, $22.5>2.80=(10,51 ; 0.01)$, highly significant.

Values followed by the same letter are not significantly different at $\mathrm{P}<0.05$ according to the Student-Neuman-Keuls test.

$50 \%$ at the highest salinity level. The differences between the varieties are more pronounced than for durum wheat.

Table 5 presents the results of bread wheat. Salinity affects the varietal ranking by decreasing the differences between the varieties; the largest difference was observed at the lowest salinity level. Only variety V7 differs significantly from the other varieties at the highest salinity level. Its yield reduction compared to the yield of variety V5 remains stable: $83 \%$ at the lowestand $82 \%$ at the highest salinity level. Among the varieties selected by ICARDA the durum wheat varieties V5 (Cham.1) and V7 (Belikh.2) and the barley varieties V3 (California Mariout) and V6 (Melusine/A) present a combination of high yield potential and high water use efficiency in a saline environment, whereas the bread wheat variety V7 (Johara.14) is less suitable under saline conditions than the other varieties. 
All the 3 cereal species were bred for drought tolerance and high yield under Mediterranean dryland conditions. Interestingly, the varieties with relatively good salt tolerance show also good yield stability. The two varieties of durum wheat, e.g.; Cham.1 and Belikh.2 are among the cultivars with high yield performance and yield stability across environments in the Mediterranean region (Nachit [25]). The additional salt tolerance to drought tolerance and yield potential may have increased the yield stability of Cham.1 and Belikh.2.

Table 5: $\quad$ Bread wheat irrigated using 3 water qualities (ECw): classification of 7 varieties according to yield and WUE.

\begin{tabular}{|c|c|c|c|c|}
\hline $\begin{array}{l}\mathrm{ECW} \\
\left(\mathrm{dSm}^{-1}\right)\end{array}$ & Variety & $\begin{array}{l}\text { Yield } \\
\left(\mathrm{Kg} \mathrm{m}^{-2}\right)\end{array}$ & Variety & $\begin{array}{l}\text { WUE } \\
\left(\mathrm{Kg} \mathrm{m}^{-3}\right)\end{array}$ \\
\hline \multirow{7}{*}{0.9} & V2 & $1.16 \mathrm{a}$ & V2 & $2.10 \mathrm{a}$ \\
\hline & V5 & $1.12 \mathrm{ab}$ & V1 & $2.05 \mathrm{ab}$ \\
\hline & V1 & $1.11 \mathrm{ab}$ & V5 & $1.98 \mathrm{ac}$ \\
\hline & V3 & $1.08 \mathrm{ab}$ & V3 & $1.94 \mathrm{ac}$ \\
\hline & V6 & $1.04 \mathrm{ac}$ & V6 & $1.83 \mathrm{bc}$ \\
\hline & V4 & $0.99 \mathrm{bc}$ & V4 & $1.78 \mathrm{~cd}$ \\
\hline & V7 & $0.93 \mathrm{c}$ & V7 & $1.60 \mathrm{~d}$ \\
\hline \multirow{7}{*}{4.0} & V5 & $1.07 \mathrm{a}$ & V3 & $1.94 \mathrm{a}$ \\
\hline & V3 & $1.04 \mathrm{a}$ & V5 & $1.93 \mathrm{a}$ \\
\hline & V1 & $1.01 \mathrm{a}$ & V1 & $1.91 \mathrm{a}$ \\
\hline & $\mathrm{V} 2$ & $1.01 \mathrm{a}$ & $\mathrm{V} 2$ & $1.88 \mathrm{a}$ \\
\hline & V6 & $1.00 \mathrm{a}$ & V6 & $1.82 \mathrm{a}$ \\
\hline & V4 & $0.95 \mathrm{a}$ & V4 & $1.80 \mathrm{a}$ \\
\hline & V7 & $0.92 \mathrm{a}$ & V7 & $1.67 \mathrm{a}$ \\
\hline \multirow{7}{*}{8.0} & V5 & $1.02 \mathrm{a}$ & V5 & $1.91 \mathrm{a}$ \\
\hline & V3 & $1.00 \mathrm{a}$ & V3 & $1.91 \mathrm{a}$ \\
\hline & V1 & $0.99 \mathrm{a}$ & V2 & $1.88 \mathrm{a}$ \\
\hline & V2 & $0.99 \mathrm{a}$ & V1 & $1.86 \mathrm{a}$ \\
\hline & V6 & $0.98 \mathrm{a}$ & V4 & $1.83 \mathrm{a}$ \\
\hline & V4 & $0.94 \mathrm{a}$ & V6 & $1.81 \mathrm{a}$ \\
\hline & V7 & $0.84 \mathrm{~b}$ & V7 & $1.54 \mathrm{~b}$ \\
\hline
\end{tabular}

F-values (ANOVA: 7 varieties, 3 salinity levels, 4 repetitions).

Dependent variable yield: variety, $5.3>3.12=(6,60 ; 0.01)$, highly significant; ECw, 7.7 $>5.18=(2,60 ; 0.01)$, highly significant; interaction, $0.39<1.66=(12,60 ; 0.10)$, not significant.

Dependent variable WUE: variety, $6.8>3.12=(6,60 ; 0.01)$, highly significant; ECw, 1.5 $<1.87=(6,60 ; 0.10)$, not significant; interaction, $0.52<1.66=(12,60 ; 0.10)$, not significant.

Values followed by the same letter are not significantly different at $\mathrm{P}<0.05$ according to the Student-Neuman-Keuls test. 


\section{Conclusion}

Durum wheat, barley and bread wheat showed an ascendant curvilinear relationship between yield and water use efficiency, which explains the similarity between the ranking order according to grain yield and that according to water use efficiency.

The durum wheat varieties showed large differences in grain yield that increased at increasing salinity. Barley also showed large differences between the varieties, even more pronounced than durum wheat but not increasing with salinity. Among the bread wheat varieties, only one variety was less suitable under saline conditions.

A varietal selection combining high yield and high water use efficiency constitutes an important point with respect to saline water irrigation management.

\section{References}

[1] Rhoades, J.D., Kandiah, A. \& Mashali, A.M., The use of saline waters for crop production, Irrigation Drainage Paper 48, FAO: Rome, 1992.

[2] Minhas, P.S., Saline water management for irrigation in India. Agricultural Water Management, 30, pp. 1-24, 1996.

[3] Reitz, L.L., Breeding for more efficient water use, is it real or a mirage? Agricultural Meteorology, 14, pp. 3-11, 1974.

[4] Pereira, L.S., Oweis, T. \& Zairi, A., Irrigation management under water scarcity. Agricultural Water Management. 57, pp. 175-206, 2002.

[5] Shideed, K., Oweis, T., Gabr, M. \& Osman, M., Assessing on-farm water use efficiency: A new approach, ICARDA publishing: Aleppo, 2005.

[6] Ayars, J.S., Phene, C.J., Hutmacher, R.B., Davis, K.R., Schoneman, R.A., Vail, S.S. \& Mead, R.M., Subsurface drip irrigation of row crops: review of 15 years research in the Water Management Research Laboratory. Agricultural Water Management, 42, pp. 1-27, 1999.

[7] Sinclair, T.R., Tanner, C.B. \& Bennett, J.M., Water use efficiency in crop production. Bioscience, 34, pp. 36-40, 1984.

[8] Burt, C.M., Clemmens, A.J., Strelkoff, T.S., Solomon, K.H., Bliesner, R.D., Hardy, L.A., Howell, T.A. \& Einsenhauer, D.E. Irrigation performance measures: efficiency and uniformity. Journal of Irrigation and Drainage Engineering, 123, pp. 423-442, 1997.

[9] Sinclair, T.R. \& Muchow, R.C., System analysis of plant traits to increase grain yield on limited water supplies. Agronomy Journal, 93, pp. 263-270, 2001.

[10] Kingsbury, R.W. \& Epstein, E., Selection for salt resistant spring wheat. Crop Science, 24, pp. 310-315, 1984.

[11] El-Hendawy, S.E., Hu, J., Yakout, G.M., Awad, A.M., Hafez \& S.E., Schmidhalter, U., Evaluating salt tolerance of wheat genotypes using multiple parameters. European Journal of Agronomy, 22, pp. 243-253, 2005. 
[12] Zhang, H. \& Oweis, T., Water yield relations and optimal irrigation scheduling of wheat in the Mediterranean region. Agricultural Water Management, 38, pp. 195-211, 1999.

[13] Oweis, T. \& Zhang, H., Water use efficiency: index for optimizing supplemental irrigation of wheat in water-scarce areas. Journal of Applied Irrigation Science, 33, pp. 321-336, 1998.

[14] Maas, E.V. \& Grattan, S.R., Crop yields as affected by salinity. Agricultural drainage, eds. R.W. Skaggs \& J. van Schilfgaarde, ASACSSA-SSSA publishing: Madison, pp. 55-108, 1999.

[15] Nachit M.M. \& Elouafi I. Durum wheat adaptation in the Mediterranean dryland: Breeding, stress physiology, and molecular markers. Challenges and Strategies for dryland Agriculture. CSSA special publishing: 32, pp. 203-218, 2004.

[16] Ceccarelli, S., Grando, S., Baum, M. \& Udupa, S.M., Breeding for drought resistance in a changing climate. Drought resistance in cereals, ed. F.W.G. Backer, CAB Publishing int: Wallingford, pp. 167-190, 2004.

[17] Ortiz-Ferrara G. \& Abdalla, O.S., Spring bread wheat improvement. Germoplasm improvement program. Annual report 1997. ICARDA publishing: Aleppo, pp. 153-168, 1997.

[18] Almsansouri M., Kinet J.M. \& Lutts S., Physiological analysis of salinity resistance in Triticum turgidum var durum Desf.: Callus versus whole plant responses. Durum wheat Improvement in the Mediterranean Region: New challenges, eds. C. Royo, M.M. Nachit \& N. Di Fonzo, Options Mediterraneenes 40, CIHEAM: Zaragosa, pp. 263-265, 2000.

[19] Zhang, H., Pala, M., Oweis, T. \& Harris, H., Water use and water use efficiency of chickpea and lentil in a Mediterranean environment. Australian Journal Agricultural Research, 51, pp. 295-304, 2000.

[20] Oweis, T., Hachum, A. \& Pala, M., Faba bean productivity under rainfed and supplemental irrigation in northern Syria. Agricultural Water Management, 73, pp. 57-72, 2005.

[21] Katerji, N., Daudet, F.A. \& Valacogne, Ch., Contribution des réreserves profondes $\mathrm{du}$ sol au bilan hydrique. Détermination et importance. Agronomie, 4, pp. 779-787, 1984.

[22] Rana, G. \& Katerji, N., Measurements and estimation of actual evapotranspiration in the field under Mediterranean climate: A review. European Journal of Agronomy, 13, pp. 125-153, 2000.

[23] Oweis, T., Supplemental irrigation: A highly efficient water-use practice, ICARDA: Aleppo, 1997.

[24] Nachit, M., Picard, E., Monneveux, P., Labhilili, M., Baum, M. \& Rivoal, R., Présentation d'un programme international d'amélioration du blé dur pour le basin méditerranéen. Cahiers Agricultures, 7, pp. 510-515, 1998.

[25] Nachit, M.M., Sorrells, M.E., Zobel, R.W., Gauch, H.G., Fischer, R.A., \& Coffman, W.R., Association of morpho-physiological traits with grain yield and components of genotype-environment interaction in durum wheat. I. Journal of Genetics \& Breeding, 46, pp. 363-368, 1992. 